ISSN 1823-626X

Malaysian Journal of Fundamental and Applied Sciences

available online at http://mjfas.ibnusina.utm.my

\title{
Synthesis of Iron sand into Nano Mn-Ferrite
}

Agus Yulianto*, Sulhadi, Ahmad Lutfi Isnaeni Azis, and Eli Dayati

Laboratory of Material Magnetism, Physics Department, Semarang State University, Kampus Sekaran Gunungpati Semarang, Indonesia (50229)

Received 10 February 2013, Revised 4 June 2013, Accepted 15 July 2013, Available online 20 July 2013

\begin{abstract}
Magnetic material, Mn-Ferrite, was prepared from iron sand using precipitation and sol-gel methods. The methods were applied to produce a homogenous and nanosized powder. The precipitation process was taken place at room temperature. $\mathrm{MnO}_{2}$ and $\mathrm{Fe}_{3} \mathrm{O}_{4}$ were dissolved with $\mathrm{HCl}$ solution to obtained $\mathrm{MnCl}_{2}, \mathrm{FeCl}_{2}$ and $\mathrm{FeCl}_{3}$ and the resulted solution were mixed. $\mathrm{NH}_{4} \mathrm{OH}$ and $\mathrm{NaOH}$ solutions were added into mixed solution to produce precipitated material. At the heating temperature of $70{ }^{\circ} \mathrm{C}, 59 \%$ of $(\mathrm{Mn}, \mathrm{Fe})_{2} \mathrm{O}_{3}$ was obtained with its particle size around $1-10 \mathrm{~nm}$. By applying sol-gel method, the iron sand was processed into iron (III) nitrate using nitric acid. Then Iron (III) nitrate was mixed with manganese (II) nitrate in the EG solvent and heated for 2 hours in $100^{\circ} \mathrm{C}$ until gel was formed. To get the powder, the gel was dried at $150^{\circ} \mathrm{C}$ for 2 hours and then continued into $350-700^{\circ} \mathrm{C}$ for 2 hours. The XRD characterization shows that the powder produced from $350^{\circ} \mathrm{C}$ heating contain $100 \%$ of $(\mathrm{Mn}, \mathrm{Fe})_{3} \mathrm{O}_{4}$ with spinel cubic structure. At the heating treatment of $700^{\circ} \mathrm{C}$, the compound was changed into $(\mathrm{Mn}, \mathrm{Fe})_{2} \mathrm{O}_{3}$ and $\mathrm{MnFeO}_{3}$. By applying Scherrer method, it was known that the average particle size was $1 \mathrm{~nm}$ and homogenous. The XRF characterization of the material resulted by both of the methods indicates that there were impurity elements such as $\mathrm{Ti}, \mathrm{Mo}, \mathrm{Zn}, \mathrm{Ca}, \mathrm{Cu}$ and $\mathrm{Ni}$ exist in the sample, since the study was used row material of iron sand.
\end{abstract}

| Iron Sand | Mn-Ferrite | Precipitation | Sol-gel |

(R) 2013 Ibnu Sina Institute. All rights reserved. http://dx.doi.org/10.11113/mjfas.v9n4.112

\section{INTRODUCTION}

Indonesia is blessed with an abandon of iron sands as iron oxide sources. As a valuable materials, generally iron sand can be found in the sea shores and beaches along Indian Ocean, from western part of Sumatra up to some islands in eastern part of Indonesia, such as in Bali, Sumbawa as well as Lombok. In Central Java, iron sand can be found in almost all beaches of southern part and in some locations of northern part, such as around the mountain of Muria [1,2].

The existence of this mineral material influences scientists of some field of study to conduct research concerning this material. Geophysical study of this material, for instance, tries to explore and to explain the mechanism of its formation, resources, etc. Physical study of iron sand is mainly used to explain its physical properties. Those studies will be resulting weighty information, which in turn can be considered in deciding its strategy of iron sand processing to become a more valuable product.

Previous study indicated that iron sand contained iron oxides such as magnetite $\left(\mathrm{Fe}_{3} \mathrm{O}_{4}\right)$, maghemite $\left(\gamma-\mathrm{Fe}_{2} \mathrm{O}_{3}\right)$ and hematite $\left(\alpha-\mathrm{Fe}_{2} \mathrm{O}_{3}\right)$ [3], the basic materials of ferrite which were considered as very most essential component in the manufacture of magnets. Considering its benefit, several researchers have studied and utilized Indonesian iron sand into ferrite magnet, and some of the studies mainly explored appropriate method of producing hard magnetic materials
$[4,5,6]$, but left the production of soft magnetic into further study.

Mn ferrite has a great influence in the development of soft magnetic materials because of their high initial magnetic permeability, saturation magnetization, electrical resistivity and low power losses [7]. This material is widely used in various applications such as microwave devices, computer memory chips, digital storage media, transformer cores, rod antennas as well as the application of telecommunication and electronics engineering [8]

Current researchs about nanoparticle were conducted to get high performence of materials [9]. Synthesis of $\mathrm{Mn}$ ferrite nanoparticles has been conducted by various methods which will yield the structure and properties of materials of different ones.

This study utilized two methods of sof magnetic production, they were precipitation and sol-gel methods. Both methods have several advantages such as producing high purity, homogeneity, small particle size, requring efficient energy, and as the reaction did not need any container, it might increase the purity of the product [9].

By comparing the two methods, this study was aimed to get best method to produce high purity and nano-sized MnFerrite.

\section{EXPERIMENTAL}

*Corresponding author. E-mail: yulianto311@yahoo.com 


\subsection{Material of Iron Sand}

Based on the previous studies, it has been known that the dominant magnetic material of iron sands is magnetite $\left(\mathrm{Fe}_{3} \mathrm{O}_{4}\right)$ and it is associated with other gauge minerals, both magnetic and non-magnetic. The gauge minerals associated in the iron sand but they are evenly distributed. There is difference of detail characteristic of iron sand from several locations [2].

Magnetite grains were extracted and purified from iron sand obtained from a disclosed location in the north coast of Java, Indonesia. The extraction used both manual and mechanical means and the purification applied grounding and sieving. This method of purification produced $99 \%$ pure magnetite powders were about [10]. Those powders were then used in this study.

\subsection{Precipitation Procedure}

Two main precursors were utilized to prepare $\mathrm{Mn}$ ferrites within precipitation method, they were $\mathrm{MnCl}_{2}$ and $\mathrm{FeCl}_{3}$. Both of them were obtained from $\mathrm{MnO}_{2}$ and $\mathrm{Fe}_{3} \mathrm{O}_{4}$ which were produced by manual extraction of iron sands that were dissolved in $36 \% \mathrm{HCl}$ in equal weight and stirred approximately for 15 minutes. The reaction equation was:

$$
\begin{aligned}
& \mathrm{MnO}_{2}+4 \mathrm{HCl} \rightarrow \mathrm{MnCl}_{2}+2 \mathrm{H}_{2} \mathrm{O}+\mathrm{Cl}_{2} \\
& \mathrm{Fe}_{3} \mathrm{O}_{4}+8 \mathrm{HCl} \rightarrow \mathrm{FeCl}_{2}+2 \mathrm{FeCl}_{3}+4 \mathrm{H}_{2} \mathrm{O}
\end{aligned}
$$

After the reaction completed, the two precursors were separated from impurities using filter papers. $\mathrm{MnCl}_{2}$ solution and iron salts solution, in concentration ratio of $1: 1$, were then mixed together. $21 \% \mathrm{NaOH}$ and $21 \% \mathrm{NH}_{4} \mathrm{OH}$ solutions were added into the final mixture in concentration ratio of $1: 2$ respectively. After reacting for about 5 minutes, black precipitated material was obtained.

The precipitated material was separated from impurities solution and it was washed using aquades for many times. This process produces mud precipitated material that was bowled to obtain half dry precipitated materials. After that heating process was administered utilizing microwave in temperature of $70^{\circ} \mathrm{C}$ for 20 minutes to get material powder [11].

\subsection{Synthesis using Sol-gel method}

Both iron(III) nitrate and manganese(II) nitrate were obtained from iron sand, by synthesizing magnetite $\left(\mathrm{Fe}_{3} \mathrm{O}_{4}\right)$ and manganese dioxide $\mathrm{MnO}_{2}$, which were extracted fron iron sand with nitric acid. Iron nitrate $\left(\mathrm{Fe}\left(\mathrm{NO}_{3}\right)_{3} \cdot \mathrm{xH}_{2} \mathrm{O}\right) 0,2$ mol and manganese nitrate $\left(\mathrm{Mn}\left(\mathrm{NO}_{3}\right)_{2} \cdot \mathrm{xH}_{2} \mathrm{O}\right) 0,1 \mathrm{~mol}$ were used as a precursor. Both of precursors were mixed and added $100 \mathrm{ml}$ of ethylene glycol as a solvent. The concentration ratio between $\mathrm{NO}_{3-}$ : EG was $1: 1$. The solution was stirred for 2 hours in a temperature of $100^{\circ} \mathrm{C}$ to obtain a homogeneous and transparent sol then cooled to reach room temperature and ethanol was added while stirring to get gel form. Ethanol addition was aimed to increase the solubility of the sol [7]. Gel was heated at a temperature of $150^{\circ} \mathrm{C}$ for 2 hours to form the nano-particle. Dried gel particles were placed on a special plate then heated at a temperature of 350 $700^{\circ} \mathrm{C}$ for 2 hours.

The powders produced by both methods were characterized by X-ray Diffraction to determine the structure and the purity produced Mn-ferrite. X-ray fluorescent was applied to explore the elements in the produced materials.

\section{RESULTS \& DISCUSSION}

\subsection{Mn-Ferrite using precipitation method}

The XRD patterns of the samples were used to determine the spinal structure of Mn ferrite by comparing with the ICDD (International Centre Diffraction Data) data. Figure 1.a shows XRD the pattern of Mn ferrite synthesized by adding $\mathrm{NH}_{4} \mathrm{OH}$. Some peaks informed Mn ferrite peaks, (JCPDS PDF\# 10-0319), they were peaks at (111), (222), (400), (422), (511) and (444). However, the intensity of the peaks was small.

Meanwhile, Fig. 1.b shows XRD pattern of Mn ferrite synthesized by adding $\mathrm{NaOH}$. There were no peaks that described Mn ferrite peaks. From XRD pattern of both samples, it could be considered that sample 1 (Fig.1.a) contained Mn ferrite and sample 2 (Fig. 1.b) did not.

The quantitative analysis revealed that sample 1 contained $59 \% \mathrm{Mn}$ ferrite and $41 \% \alpha \mathrm{Fe}_{3} \mathrm{O}_{4}$; however they were not completely pure in spinal-cubic structure, since the precipitation process was conducted at room temperature. Further study which conducts the process in higher temperature should be conducted to find out best temperature for the process resulting higher percentage of $\mathrm{Mn}$ ferrite. On the other hand, sample 2 only contained $10 \% \mathrm{MnO}_{2}, 55 \%$ $\mathrm{Fe}_{3} \mathrm{O}_{4}, 35 \% \mathrm{Fe}_{2} \mathrm{O}_{3}$ hence; $\mathrm{Mn}$ ferrite has not obtained yet.

XRF result of precipitated powder sample shows that there were many impurities in the powder. It is possibly because the material used in experiment was raw material iron sands Iron sand can be consider as secondary rock, which was formed from igneous rock Table 1 shows types of impurities in precipitated samples..

\subsection{Mn-Ferrite produced using sol-gel method}

Iron(III) nitrate and manganese(II) nitrate were obtained by synthesizing basic material with nitric acid, using oxalic acid as a catalyst. The synthesizing of iron nitrate follows this chemical process:

$$
\begin{aligned}
& 2 \mathrm{Fe}_{3} \mathrm{O}_{4}+24 \mathrm{HNO}_{3}+2 \mathrm{C}_{2} \mathrm{H}_{2} \mathrm{O}_{4} \stackrel{90^{\circ} \mathrm{C}}{\longrightarrow} \\
& 6 \mathrm{Fe}\left(\mathrm{NO}_{3}\right)_{3}+3 \mathrm{Fe}\left(\mathrm{NO}_{3}\right)_{2}+14 \mathrm{H}_{2} \mathrm{O}+4 \mathrm{CO}_{2}
\end{aligned}
$$

Meawhile manganese nitrate synthesizing reaction is: $\mathrm{MnO}_{2}+2 \mathrm{HNO}_{3}+\mathrm{C}_{2} \mathrm{H}_{2} \mathrm{O}_{4} \stackrel{90^{\circ} \mathrm{C}}{\longrightarrow}$ 
$\mathrm{Mn}\left(\mathrm{NO}_{3}\right)_{2}+2 \mathrm{H}_{2} \mathrm{O}+2 \mathrm{CO}_{2}$

The reaction product of iron nitrate formed golden brown solution which is comprised of compound $6 \mathrm{Fe}\left(\mathrm{NO}_{3}\right)_{3}$ and $\mathrm{Fe}\left(\mathrm{NO}_{3}\right)_{2}$. The brown colour is caused from ion $\mathrm{Fe}^{3+}$ whereas the yellow from ion $\mathrm{Fe}^{2+}$. Product solution is more brown colour show that ion $\mathrm{Fe}^{3+}$ more dominant than ion $\mathrm{Fe}^{2+}$. If the solution letting settle then formed a white crystalline anhydrate ferrous nitrate which is a solid form of iron oxide. Iron nitrate crystals are highly reactive and easily oxidized. While the synthesis reaction of manganese oxide and nitrate acid solution formed a ligth red manganese nitrate $\mathrm{Mn}\left(\mathrm{NO}_{3}\right)_{2}$. It's very easily to be precipitate (crystalization).

$\mathrm{Mn}$ ferrite powders obtained by sol gel method. Percusor solution of iron nitrate and manganese nitrate dissolved in ethylene glycol (EG). Base on the oxidation reaction principle of ethylene glycol and $\mathrm{NO}^{-3}$ ions into glyoxylate dyanion combination complex formed a heteropolynuclear $\mathrm{Fe}_{2} \mathrm{Mn}(\mathrm{OH})_{4}\left(\mathrm{C}_{2} \mathrm{H}_{2} \mathrm{O}_{4}\right) \mathrm{H}_{2} \mathrm{O}$. While NO gases and $\mathrm{HNO}_{3}$ will be lost during the process of sol-gel.

The graph in figure 2 indicates prominent peaks at an angle $2 \theta 30.2231^{\circ}, 35.6027^{\circ}, 43.3097^{\circ}, 53.7787^{\circ}, 57.2675^{\circ}$, $62.9088^{\circ}$, and $74.3963^{\circ}$. The peaks were related to the phase of formed compound. Identified peaks indicate that the compound is $(\mathrm{Fe}, \mathrm{Mn})_{3} \mathrm{O}_{4}$. By XRD quantitative analysis it is known that the compound is fully $(\mathrm{Fe}, \mathrm{Mn})_{3} \mathrm{O}_{4}$, it is close to appropriate data of ICDD PDF39-1346. Using integrated software in XRD system it can be identified that the compounds is cubic of $(\mathrm{Fe}, \mathrm{Mn})_{3} \mathrm{O}_{4}$ with space group FD-3m (No. 227). (Fe, Mn $)_{3} \mathrm{O}_{4}$ is a special $\mathrm{Mn}$ ferrite spinel which there $\mathrm{Mn}^{2+}$ are substituted in to spinel. Spinel $(\mathrm{Fe}, \mathrm{Mn})_{3} \mathrm{O}_{4}$ consist of $\mathrm{FeFe}_{2} \mathrm{O}_{4}$ or $\mathrm{MnFe}_{2} \mathrm{O}_{4}$. Both are ferrimagnetic materials.

Table 1. The existence impurities in the powder of precipitated material

\begin{tabular}{cccc} 
Flement & Concentration/Percent & Flement & Concentration/Percent \\
\hline & $\mathbf{( \% )}$ & & (\%) \\
$\mathrm{Ti}$ & 5.05 & $\mathrm{Cr}$ & 0.30 \\
$\mathrm{Si}$ & 2.10 & $\mathrm{P}$ & 0.27 \\
$\mathrm{Al}$ & 1.90 & $\mathrm{Re}$ & 0.20 \\
$\mathrm{Bi}$ & 0.73 & $\mathrm{Ca}$ & 0.19 \\
$\mathrm{Eu}$ & 0.66 & $\mathrm{Zn}$ & 0.09 \\
$\mathrm{~V}$ & 0.48 & $\mathrm{Ni}$ & 0.004 \\
$\mathrm{Rb}$ & 0.45 & $\mathrm{Yb}$ & 0.003 \\
\hline
\end{tabular}

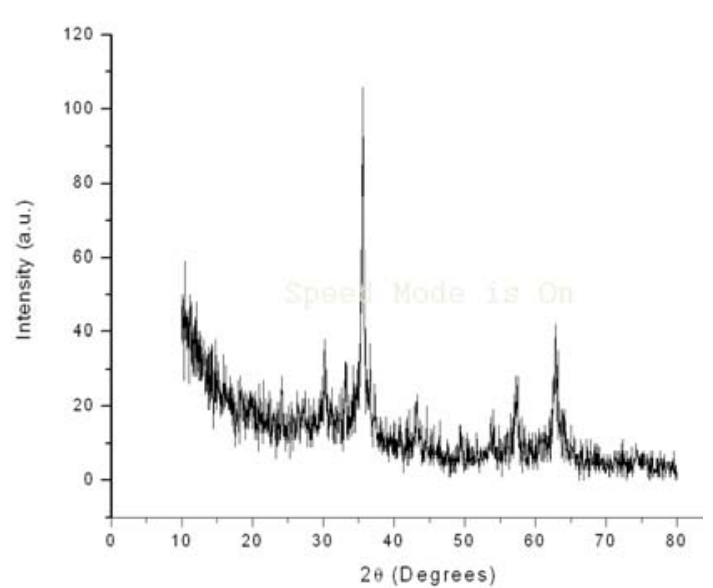

(a)

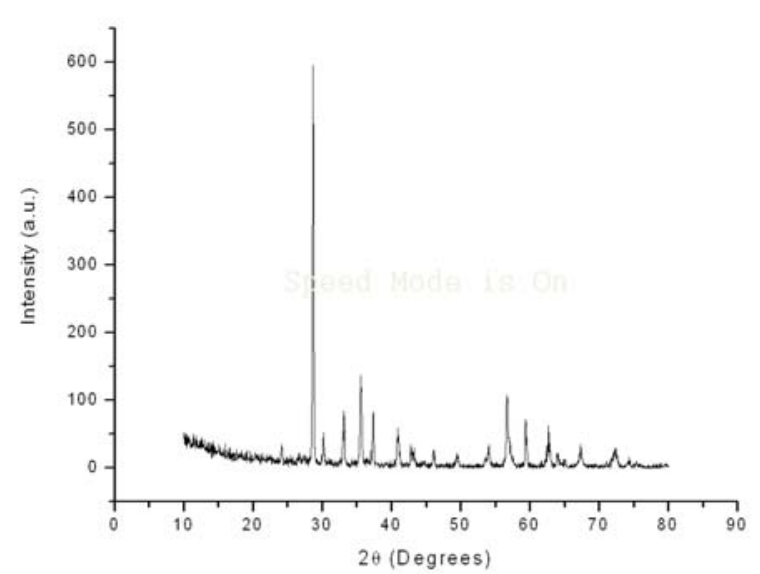

(b)

Fig. 1 XRD Pattern of the precipitated material (a) using $\mathrm{NH}_{4} \mathrm{OH}$ and (b) using $\mathrm{NaOH}$

In the spinel $(\mathrm{Fe}, \mathrm{Mn})_{3} \mathrm{O}_{4}$, divalent ions $\mathrm{Fe}^{2+}$ dan $\mathrm{Mn}^{2+}$ arrange the octahedral lattice dan trivalent ions $\mathrm{Fe}^{3+}$ are tetrahedral ones. Magnetic ions will be paired where the sub lattice A dan B are antipararel. Each sub lattice has one ion $\mathrm{Fe}^{2+}$ in sub lattice $\mathrm{B}$ and ion $\mathrm{Fe}^{3+}$ in sub lattice $\mathrm{A}$. There is unbalanced antiparalel couple because of a magnetic 
moment pair thus generated by ion $\mathrm{Fe}^{2+}$. So the material is ferrimagnetic.

In the compoud of $\mathrm{MnFe}_{2} \mathrm{O}_{4}$, the presence of ions $\mathrm{Mn}^{2+}$ repalced the ions $\mathrm{Fe}^{2+}$ in the $\mathrm{Fe}_{3} \mathrm{O}_{4}$ lattice. It is related to the activation energy that is kinetic [temperature] reaction. Activation energy for the formation of ferrite is not the same for several metals. The activation energy associated with the temperature required for the formation of ferrite between $20^{\circ} \mathrm{C}-100^{\circ} \mathrm{C}$ in sol gel method. Activation energy of manganese is at temperature of $100^{\circ} \mathrm{C}[12,13]$. There is $\mathrm{FeFe}_{2} \mathrm{O}_{4}$ compounds because percusor used are $\mathrm{Fe}\left(\mathrm{NO}_{3}\right)_{3}$ and $\mathrm{Fe}\left(\mathrm{NO}_{3}\right)_{2}$. Ion $\mathrm{Fe}^{3+}$ from $\mathrm{Fe}\left(\mathrm{NO}_{3}\right)_{3}$ tends to be $\mathrm{Fe}_{2} \mathrm{O}_{3}$ whereas ion $\mathrm{Fe}^{2+}$ from $\mathrm{Fe}\left(\mathrm{NO}_{3}\right)_{2}$ tends to be $\mathrm{FeO}$.

$$
\begin{aligned}
\mathrm{Fe}\left(\mathrm{NO}_{3}\right)_{3}+\mathrm{Fe}\left(\mathrm{NO}_{3}\right)_{2}+\mathrm{Mn}\left(\mathrm{NO}_{3}\right)+x \mathrm{H}_{2} \mathrm{O}+\mathrm{C}_{2} \mathrm{H}_{4}(\mathrm{OH})_{2} \stackrel{100^{\circ} \mathrm{C}}{\longrightarrow} \\
\mathrm{Fe}_{2} \mathrm{Mn}(\mathrm{OH})_{4}\left(\mathrm{C}_{2} \mathrm{H}_{2} \mathrm{O}_{4}\right)_{2} \cdot x \mathrm{H}_{2} \mathrm{O}+4 \mathrm{NO}+3 \mathrm{HNO}_{3}
\end{aligned}
$$
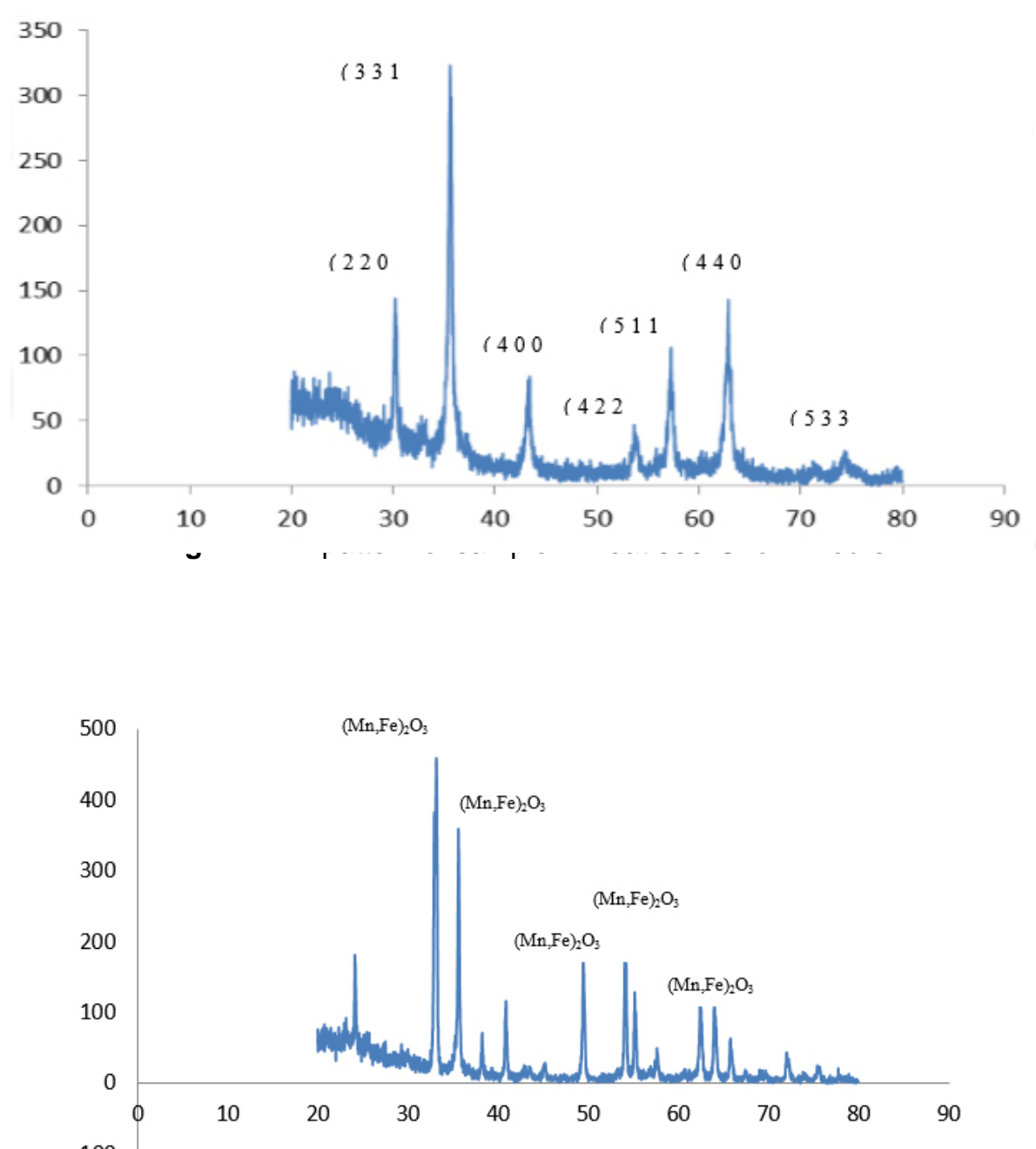

$-100$

XRD pattern of sample 2 shows that it's peaks is different from sample 1 . There is a phase trasformation from magnetite in sample 1 change into hematite phase in the heating of $700^{\circ} \mathrm{C}$. The oxidation of magnetit $\mathrm{Fe}_{3} \mathrm{O}_{4}$ will be change in to maghemit $\gamma-\mathrm{Fe}_{2} \mathrm{O}_{3}$ or hematit $\alpha$ -
$\mathrm{Fe}_{2} \mathrm{O}_{3}$. It will not occure at a lower temperature because the hematite formed in the outer layer of grains of magnetite coating will protect it from further oxidation ${ }^{[8]}$. The advent of hematite confirmed by XRD spectra where peaks are formed at an angle which is the main peak of 
hematite. The angles are $33,17^{\circ}, 35,64^{\circ}, 49,50^{\circ}, 54,11^{\circ}$, $62,48^{\circ}$ dan $64,04^{\circ}$. It's shown at figure 2 .

The analysis results show that formed $70.46 \%$ of $(\mathrm{Mn}, \mathrm{Fe})_{2} \mathrm{O}_{3}$ compound having space group R-3 (No. $167)$ is formed. It has a trigonal structure and $29.54 \%$ of cubic $\mathrm{MnFeO}_{3}$ with space group I a-3 (No. 206). The advent of $(\mathrm{Mn}, \mathrm{Fe})_{2} \mathrm{O}_{3}$ and $\mathrm{MnFeO}_{3}$ are caused by the oxidation and reduction process during heating. This reaction can occur depending on the oxygen partial pressure and heating temperature heating [3]. Ferrite formation must occur at a lower pressure than the pressure of the oxygen in the air, so it is quite heated at low temperatures. If the high temperature is given, so as the partial pressure of oxygen in the air is higher then the decomposition of ferrite.

$$
(\mathrm{Mn}, \mathrm{Fe})_{3} \mathrm{O}_{4}+\left[\mathrm{O}_{2}\right] \rightarrow(\mathrm{Mn}, \mathrm{Fe})_{2} \mathrm{O}_{3}+\mathrm{MnFeO}_{3}
$$

With the Scherrer method, particles size can be known by the formula

$$
d=\begin{gathered}
0,94 \lambda \\
\beta \cos \theta
\end{gathered}
$$

where $\lambda$ is wave length of used Xray, $\beta$ is full width half maximum (FWHM) and $\theta$ is bragg angle. The data is taken from XRD spectrum data. From the calculations yield an average particle size is $1 \mathrm{~nm}$.

The results of XRF sample 1 shows a rasio of the composition of $\mathrm{Fe}$ and $\mathrm{Mn}$ are 58,0 \% and 32,9\%. Likewise rasio of the composition sample $2 \mathrm{Fe}$ and $\mathrm{Mn}$ are $59,3 \%$ banding $33,3 \%$. This composition is suitable for the formation of $\mathrm{Mn}$ ferrite $\left(\mathrm{MnFe}_{2} \mathrm{O}_{4}\right)$ that $\mathrm{Fe}$ and $\mathrm{Mn}$ rasio are 2:1. As for the other metals that arise include $\mathrm{Ti}, \mathrm{Mo}, \mathrm{Zn}, \mathrm{Ca}, \mathrm{Cu}$ and $\mathrm{Ni}$ are impurity of the iron sand. Extraction of natural iron sand is not really pure $\mathrm{Fe}_{3} \mathrm{O}_{4}$. Homogeneity of the elemental composition of the compound seen in the sample are almost the same. This shows the sol gel method gives good homogenity.

Based on the result of the characterization, it can be stated that Mn-Ferrite produced using precipitation and sol-gel methods has different properties relatively. Mn-Ferrite produced by sol-gel method has grain nanosize, purity and homogenity better than those produced by precipitation.

\section{CONCLUSION}

Mn ferrite can be synthesized from iron sand by applying precipitation and sol gel methods. However, the later produced higher purity and nano sized of Mn-ferrite than the former method. XRD characterization result indicates that temperature of heating affects the crystal structure in both methods. In Sol gel method, heating process of $350^{\circ} \mathrm{C}$ is effective to produce $\mathrm{Mn}$ ferrite powders having $100 \%$ cubic inverse spinel structure. Whereas at $700^{\circ} \mathrm{C}$ the phase is phase trasformed into trigonal (Mn, $\mathrm{Fe})_{2} \mathrm{O}_{3}$ and cubic $\mathrm{MnFeO}_{3}$ which composition $70,46 \%$ and $29,54 \%$. By Scherrer method, the average of particle size is 1 nanometer. From the characterization results obtained XRF elemental composition information in a sample consisting of elements $\mathrm{Fe}, \mathrm{Mn}$ and elements which are impurities such as $\mathrm{Ti}, \mathrm{Mo}, \mathrm{Zn}, \mathrm{Ca}, \mathrm{Cu}$ and $\mathrm{Ni}$ were scattered evenly between the two samples indicates equitable homogeneity.

\section{ACKNOWLEDGEMENT}

The authors thank the Central Laboratory of Faculty of Mathematics and Natural Sciences Universitas Negeri Malang, especially to Mr. Abdullah Fuad, M.Sc. for XRD and XRF facilities as well as to Indonesian Government for funding the project.

\section{REFERENCES}

[1] Yulianto.A, S. Bijaksana, W. Loeksmato, Study on Magnetic Properties of Iron Sand from Central Java, Proceeding of Join Asia Oceania Geosciences Society (AOGS) $1^{\text {st }}$ Annual Meeting and $2^{\text {nd }}$ APHW Converence, Singapore, 57-OSE-A1615 (2004) 132.

[2] Yulianto.A, S. Bijaksana, W. Loeksmato \& D. Kurnia, Kontribusi Fisika Indonesia, 14 (2), (2003) 63-66.

[3] Cornell, R. M., Iron Oxide . Wiley VCH., 2003.

[4] Yulianto.A, S. Bijaksana, W. Loeksmato \& D. Kurnia, The Synthesis of Magnetic Material of Barium and Strontium Hexaferrite Made of Iron Sand, Presented on Kentingan Physics Forum, UNS Surakarta, September 2006

[5] Ridwan, Sulungbudi, G.T., dan Mujamilah, Jurnal Sains Materi Indonesia, 5(1), (2003) 29-33.

[6] Dedi, N.Idayanti, S.Djaja, Jurnal Fisika HFI, A5 (0526) (2002) 86-90.

[7] Ping Hu, H. Yang, D. Pan \& H. Wang, Journal of Magnetic and Materials, 322 (2010) 173-177.

[8] Ahmed, M. A., N. Okasha \& S. I. El-Dek, Preparation and Characterization of Nanometric Mn Ferrite via Different Methods. IOP Publishing : Nanotechnology, 19, 2008.

[9] Kumar, P., P. Mishra \& S. K. Sahu, International Journal of Scientific \& Engineering Research, 2 (2011) 1-4.

[10] Yulianto.A, S. Bijaksana, W. Loeksmato \& D. Kurnia, Extraction and Purification of Magnetit $\left(\mathrm{Fe}_{3} \mathrm{O}_{4}\right)$ from Iron Sand, Proceedings of the Annual Physics Seminar, ISBN: 979-98010-0-1, (2003) 102

[11] Aji, Mahardika Prasetya, "Kajian Sifat Magnetik Magnetit $\left(\mathrm{Fe}_{3} \mathrm{O}_{4}\right)$ Hasil Penumbuhan dengan Metode Presipitasi Berbahan Dasar Pasir Besi," Program pascasarjana. ITB, Tesis, 2008.

[12] Stefanescu, M., C. Caizer, M. Stoia \& O. Stefanescu, Journal of Optoelectronics and Advanced Materials, 7(2005) 607-614

[13] Dahotre, S G \& L. N. Singh. 2011. Study of Magnetic Properties of Nano Structured Mn-Zn Ferrite. Archives of Physics Research, 2 (1), (2011) 81-89. 